\title{
Love of Money and Fraud Tendency: Religiosity as Moderating Variable
}

\author{
Veni Nopeanti, Tarjo ${ }^{1}$, Bambang Hariadi ${ }^{2}$ \\ \{veninop@gmail.com ${ }^{1}$ \} \\ Fakultas Ekonomi dan Bisnis Universitas Trunojoyo Madura ${ }^{1,2}$
}

\begin{abstract}
The number of cases of fraud in higher education institutions in Indonesia is very apprehensive. This research aims to determine whether the love of money is one factor that affects fraud tendency at higher education institutions with religiosity as a moderation variable. The data used are questionnaires collected from the respondents of the finance staff in higher education. To test the hypothesis used Moderated Regression Analysis (MRA). The results show that love of money has an effect on fraud tendency. Religiosity is also a moderating variable of the influence of love of money on fraud tendency.
\end{abstract}

Keywords: Fraud Tendency, Higher Education, Love of Money, Religiosity.

\section{Introduction}

Education has an important role in the growth of a country. Education is also one of the indicators of whether a country is progressing or not in forming a generation that is creative, innovative, and independent. To create this, the government must have a good education system to improve the quality of education [1]. The government's duty to improve the quality of education is regulated in education law which states that national education functions to develop capabilities and form dignified national character and civilization in order to educate the nation's life, aiming at developing potential students to become human beings who believe and fear the Almighty God, noble, healthy, knowledgeable, capable, creative, independent, and a democratic and responsible citizen.

In carrying out its duties and functions, these educational institutions find many obstacles, including fraud in education. The budget for the education sector is $20 \%$ of the state budget. The amount of education budget allocation in the APBN in 2015 was Rp. 409.1 trillion and in 2016 the number increased to Rp. 424.7 trillion. Ironically, with the increasing allocation of the APBN budget for the education sector, there is still a deviation in the management of these education funds. Various kinds of inefficiencies in managing the education budget are always found by government inspection such as the BPK and BPKP.

Fraud in higher education institutions generally occurs because of the underlying factors for doing so. Fraud Triangle Theory states that the cause of someone committing fraud is because of the pressure factor. Pressure motivates someone to take illegal actions. Pressure as one of the causes of fraud can be caused due to financial pressure [2]. Financial pressure is caused by the nature of greed in a person [3]. The survey that held by KPMG shows that the reason for someone to commit fraud $66 \%$ is due to greed and to gain personal financial benefits [4]. The concept of greed has a close relationship with love of money [5]. The tendency to commit fraud is influenced by the existence of love of money [6]. All humans 
naturally love of money, but in different degrees or levels. Excessive love of money causes someone to do anything to get money, including doing unethical actions that lead to fraud [7].

The love of money factor in the tendency for fraud is also influenced by the presence of intrinsic religiosity [8]. Religiosity can be interpreted as trust in God accompanied by commitment and following certain principles set by God [9]. Religiosity has an effect on fraud in the workplace, where someone with a high religiosity level behaves better, so he tries not to commit fraud [10] The high and low level of love of money is influenced by religiosity. Someone with religiosity tends to a low level of love of money [11]. Someone who is motivated by money or who places money as a top priority (high love of money) will tend to see cheating more acceptable, but with a high level of intrinsic religiosity can positively impact the ethics of money against fraud, so individuals who are intrinsically more religious can see tax cheating more unethical in money ethics compared to individuals with low intrinsic religiosity [8].

In line with the description above, this study aims to examine the effect of moderating religiosity between love of money on fraud tendency. This research will be conducted at Universities in East Java.

\section{Theoretical Background}

\subsection{Fraud}

Fraud as an act carried out by internal or external parties with a purpose to hide something. This action is usually illegal and shows violations, such as the error statement, policy violation, unethical actions, or a matter of perception. This action causes the loss of the company's funds, the value of the company, the company's reputation, or unauthorized benefits received by the person or others [12].

An understanding of why people are committing fraud based on the Fraud Triangle Theory stated that the act of fraud motivated by "non-shareable financial problem," where inside there are three elements. The first pressure or incentives to motivate someone to behave illegally. Pressure, usually arising from problems that can not be shared. Pressure identified as fraudulent, behavior common motivators have been categorized according to: (1) financial pressures; (2) the crime; (3) the working pressure; and (4) other pressures such as the desire to have more material. The second is an opportunity, a situation which made the fraud emerged. The opportunity arose when the perpetrator sees where there is a way to use his position to solve their financial problems, and know that they don't seem to be getting caught. The third is the rationalization, Justification that the crime committed is acceptable and justifiable. Rationalization is one motivation that led to the occurrence of acts of fraud [2].

\subsection{Love of Money}

A person's perception of money began when he was a child. The behavior of money is learned from character, built on parent learning and observation of financial experience in the family, then refined through socialization and experience. Discussions about money are very rare and even considered taboo [13]. Love of money is interpreted as a negative thing and even considered taboo by certain people. Some people also stated that love for money is the root of all evil [7]. 
Love of Money is defined as (1) A person's attitude towards money with behavior, affective and cognitive components; (2) Meaning of a person's attribute to money [14]. Love of money does not represent someone's "needs" but reflects someone's "desires" and "values". "Necessity" means something that someone needs for life, while "value" is something that is attempted to be obtained and or stored or considered beneficial by someone. "Value" relies on awareness at a certain level of the object or condition sought, where "necessity" is not. Furthermore, "value" is more of a hope that reflects satisfaction [15]. Love of money is a subjective feeling and one's attitude towards money, seen from the components of behavior, affective and cognitive which have four specific factors and reflect the combination of the idea that money is a motivation, money symbolizes success money is very important and the desire to be rich.

\subsection{Religiosity}

The impact of religion on social and economic life has long been a debate. At present, some studies pay more attention to behavior and aim to explore the relationship between religious beliefs and ethics in business [16]. Furthermore, religiosity in the concept of Muslim Religiosity-Personality Inventory (MRPI) can be understood as two main things, namely Islamic Worldview and Religious Personality. Islamic Worldview reflects the paradigm of tauhid (the doctrine of divine unity / unity of God) and is assessed through the basis of belief in Islam (aqeedah), which specifies that a Muslim must know, believe, and in his heart understand about God and religion as determined by the Qur'an and The Sunnah of the Prophet Muhammad, which is the two main sources of Islamic religious law. Religious Personality is a person's religious view of right behavior (pious deeds), or certain ways a person expresses his characteristics to adapt to diverse situations in the world - aspects of one's manifestation through personal identity, the definition of life, and worldview based on teachings Islam and motivated by his belief in God. Religious Personality includes behavior, motivation, attitudes, and emotions that reflect the teachings and commands of Islam. Religious Personality is represented by statements relating to specific rituals or worship that reflect one's direct relationship with God and daily mu'amalat, or religious guidance that guides behavior towards family, fellow human beings and other creations. The main aspects that underlie the aspects of Religious Personality are akhlaq Islamiyyah or Islamic ideas about the character underlying religious personality [17]. Two main things in MRPI, Religious Personality is a scale of religiosity that is suitable for adaptation in several religions. Religious Personality is a manifestation of one's religious views and awareness of God in one's behavior as taught by all religions. This refers to a variety of behavioral actions, namely actions towards God; actions against fellow humans; actions against non-humans (animals, environment, etc.); and actions towards oneself [18].

\subsection{Love of Money and Fraud}

Money is a factor that cannot be separated from human life. Money is a very important aspect of daily life [19]. Research on a person's behavior towards money has been carried out, among others [19][13][20][21]. The concept of love of money scale is introduced to measure the level of one's love for money and its relationship to crime. Love of money measures a person's subjective feelings about money. Rich or poor is measured subjectively, a person may be financially poor, but psychologically he is rich. It makes sense if someone with a high level 
of love of money is motivated to do anything to earn money and mentally will be more attached to unethical behavior (fraud) in the workplace compared to someone with a low level of love of money. Love of money as a desire for money but not their needs and the importance of money and one's personal behavior towards money [15]. When money is used as motivation, someone will do anything to get it. This motivation will lead to positive or negative actions. On the plus side, people with a high love of money tend to take action to achieve their goals and create more wealth quickly, efficiently, and effectively than their counterparts to make more money. Negative actions of love of money cause a person to become greedy, always feel dissatisfied and will do anything to get money, including fraud. Money can be used as a tool to fulfill one's basic needs, but someone with a high level of love of money will never be satisfied with money [14]. Love of money (someone's desire and aspirations for money) is more strongly related to unethical behavior than materialism (one's goal to live better through consumption or ownership) [20]. Based on this, the hypotheses of this study are :H1: Love of Money affects fraud tendency.

\subsection{Religiosity, Love of Money and Fraud}

Religiosity is defined as one's belief in religious values, seen from obedience and behavior in daily life [22]. Someone with high intrinsic religiosity has a low level of love of money [11]. People with intrinsic religiosity will assume that money ethics and fraud are unethical, they assume that money is not everything in fulfilling their needs, because individuals with intrinsic religiosity will reflect the needs of their lives with motivation and religiousity that he believes [23]. In this case, intrinsic religiosity moderates the influence of ethic money on fraud [8].

Research on Islamic Work Ethic (IWE) also shows that individuals with high perceptions of IWE are individuals who apply Islamic values to their work and daily behavior can use the money better [24]. Furthermore, with the application of Islamic religiosity, a Muslim always strives to behave well in daily life and avoid cheating behavior. This is because of their fears and beliefs in God that they feel that God is always watching whenever and wherever they are [25]. Based on this, the hypotheses of this study are: H2: Religiosity moderates the influence of love of money on the fraud tendency.

\section{Research Methodology}

\subsection{Research data}

The sample in this study is the financial staff education staff at University in East Java because the finance department is the position that is considered most vulnerable to fraud. The type of data used in this study is primary data. Primary data used in this study is in the form of data containing perceptions, opinions, and characteristics of respondents. Primary data from this study were obtained from the answer of the respondents questionnaire Primary data in this study were characteristics of respondents, namely, gender, age, last education, and length of work and perceptions and opinions of respondents related to love of money, and fraud tendency. 


\subsection{Operational Definition and Measurement of Variables}

This study uses 3 types of variables, dependent variable, independent variable and moderating variable. The dependent is fraud tendency in the higher education sector. The independent variable is love of money. The moderating variable is religiosity.

Table 1. Operational Definition and Measurement of Variables

\begin{tabular}{lll}
\hline Variable & Definition & Measurement \\
\hline \multirow{3}{*}{ Love of Money } & $\begin{array}{l}\text { Subjective feeling and one's attitude towards } \\
\text { money is seen from the components of be- } \\
\text { havior, affective, and cognitive. }\end{array}$ & $\begin{array}{l}\text { Love of Money Scale } \\
\text { [26] }\end{array}$ \\
& $\begin{array}{l}\text { The tendency to make misstatement arising } \\
\text { from improper treatment of assets and mis- }\end{array}$ & \\
& statement or deliberate omission of amounts & Farud Tendency \\
Fraud Tendency & or disclosures in financial statements to trick & \\
& users of financial statements. & \\
& $\begin{array}{l}\text { The realization of one's religious views and } \\
\text { awareness of the existence of God in a per- }\end{array}$ & Muslim Religiosity \\
& son's behavior which refers to various behav- & Personal Inventory \\
& ioral actions, actions towards God; actions & [17][18] \\
against humans; actions against non-humans. & \\
\hline
\end{tabular}

\subsection{Hypothesis Testing}

In testing the hypothesis one and that is whether love of money has an effect on fraud tendency used simple regression test whereas to test the second hypothesis is to determine whether religiosity is a moderating variable of the influence of love of money on the tendency of fraud to be used moderated regression analysis (MRA). The model of the relationship equation between variables used is as follows:

$$
\begin{gathered}
Y=\alpha+\beta 1 X 1+e \\
Y=\alpha+\beta 1 X 1+\beta 2[X 1 * X 3]+e
\end{gathered}
$$

\section{Analysis}

\subsection{Overview of the Observation Unit}

This research was carried out using primary data obtained from the distribution of questionnaires to respondents, namely the financial staff education staff at BH PTN in East Java. The criteria of the respondents in question are the education staff of the finance department, namely the treasury sub-section, reporting and accounting, the budget and treasurer in the Faculty / Department / Directorate / Bureau / Institution / Unit. The number of questionnaires distributed to respondents in this study were 145 questionnaires, while the questionnaire returned as many as 118 copies. The percentage of return on questionnaires is $81 \%$, the percentage of questionnaires that are not returned is $19 \%$. Of the 118 questionnaires that were re- 
turned, there were three questionnaires or $2 \%$ which could not be processed because the respondents did not complete the questionnaire in full.

\subsection{Love of Money and Fraud Tendency}

The love of money equation model and fraud tendency is used to test the first hypothesis. To test the first hypothesis, is there an influence between the variable love of money and the tendency of fraud variables used simple linear regression analysis.

Table 2. Result of Hypothesis 1

\begin{tabular}{llll}
\hline Variable & Coefficient & $\mathrm{t}$ & Sig \\
\hline constant & 8.798 & 3.827 & 0.000 \\
Love of money & 0.183 & 3.528 & 0.001 \\
Adjusted R Square $=0.091 ; \mathrm{R}=0.315 ;$ & & \\
R Square $=0.099 ; \mathrm{F}$ hitung $=12,445 ;$ Sig F $=0.000$ & \\
\hline
\end{tabular}

From table 3 above, it can be explained that the constant value of 8.798 means that if the variable love of money (X1) is 0 , or in other words the independent variable is ruled out, the magnitude of the value of fraud tendency is 8.798 . The parameter coefficient of the love of money variable (X1) of 0.183 means that if the variable love of money has increased by $1 \%$, fraud tendency will increase by 0.183 . The coefficient value indicates a positive value means love of money has a positive effect on the fraud tendency. The results of testing the first hypothesis can be seen the value of t-count for the variable love of money that is equal to 3.528 . This value is greater than the t-table value of $1.98(3.528>1.98)$ with a significance value of 0.001 smaller than $0.05(0.001<0.05)$, thus the first hypothesis $(\mathrm{H} 1)$ is accepted and can be concluded that love of money has a significant effect on the tendency of fraud. Adjusted R Square value (R2) in table 2 is 0.091 , which indicates that fraud tendency can be explained by the variable love of money of $9.1 \%$ while $91.9 \%$ is influenced by other variables.

\subsection{Love of Money, Fraud Tendency and Religiosity}

Furthermore, to test the second hypothesis, whether religion is a moderating variable of love of money to fraud tendency using moderated regression analysis.

Table 3. Result of Hypothesis 2

\begin{tabular}{llll}
\hline Variable & Coefficient & $\mathrm{t}$ & $\mathrm{Sig}$ \\
\hline constant & 7.929 & 3.827 & 0.000 \\
Love of money & 1.867 & 7.940 & 0.000 \\
Love of money x religiosity & -1.539 & 7.060 & 0.000 \\
Adjusted R Square $=0.350 ; \mathrm{R}=0.601 ;$ & & \\
$\mathrm{R}$ Square $=0.362 ; \mathrm{F}$ hitung $=31.713 ;$ Sig F $=0.350$ & & \\
\hline
\end{tabular}


From table 3 above, it can be explained that the Adjusted R Square value (R2) is 0.350 meaning that $35 \%$ of the fraud tendency variables can be explained by independent variables love of money, religiosity, and moderation between love of money and religiosity. The remaining $65 \%$ is explained by other variables. The $\mathrm{F}$ test produces a calculated $\mathrm{F}$ value of 31,713 with a significance level of 0,000 . Because the significance is far less than 0.05 , the regression model can be used to predict the tendency of fraud, or it can be said that love of money and moderation between love of money and religiosity jointly influence the tendency of fraud. From the results of testing the second hypothesis, it can be seen that the value of tcount for the moderating variable of religiosity in the influence of love of money on fraud is equal to 7.060. This value is smaller than the t-table value of $1.98(7.060>1.98)$ with a significance value of 0.000 smaller than $0.05(0,000>0.05)$. Thus the second hypothesis $(\mathrm{H} 2)$ is accepted and can be concluded that religiosity is a moderating variable of love of money towards the fraud tendency. The parameter coefficient value of 1.539 shows a negative value, which means that moderation of religiosity weakens the influence of love of money on the tendency of fraud.

\section{Discussion}

\subsection{Effect of Love of Money on Fraud}

The results of this study indicate that love of money affects the tendency of fraud. The higher the level of love of money, the more likely it is to commit fraud. Conversely, the lower the level of love of money, the less likely the tendency to commit fraud, which is in accordance with the other research that love of money is the root of evil [7]. Someone with a high level of love of money is motivated to take any action to get money and mentally will be more attached to unethical behavior (fraud) in the workplace compared to someone with a low level of love of money. Negative actions about the high level of love of money cause a person to become greedy, always feel dissatisfied, and will do anything to get money, including fraud. Money can be used as a tool to fulfill one's basic needs, but someone with a high level of love of money will never be satisfied with money [14]. Love of money in this study is assumed to be a stress factor in fraud triangle theory. Pressure, in this case, is financial pressure related to greed. The concept of greed is closely related to love of money. Someone with a high level of love of money considers that money is something important and a symbol of success and achievement, it will encourage him to tend to do fraud.

\subsection{Religiosity moderates the influence of love of money on the tendency of fraud}

The results of this study indicate that religiosity moderates the influence of love of money on the tendency of fraud. Someone with a high level of love of money will tend to commit fraud, but with religiosity will reduce the level of a tendency to do fraud. With the high level of religiosity, it will reduce the level of love of money and also reduce the tendency of fraud. Conversely, the interaction of the high love of money and religiosity will reduce the tendency of fraud. Religiosity will affect the relationship between love of money and the tendency of fraud. Highly religious people tend to view unethical behavior as more negative than less religious people because they consider such behavior to be sinful [26]. People with religiosity orientation will assume that love of money and cheating are unethical actions, they assume 
that money is not everything in fulfilling their needs, because individuals with religiosity will relevance their needs in his life with the motivations and religious meanings he believed in, so religiosity moderated love of money on fraud [8][23]. Someone who has a high religiosity character will base his daily activities based on his religious principles. For this reason, in this case, religiosity will reduce the tendency of fraud.

\section{References}

[1] R. Rachmanta and S. Ikhsan, "Analisis Faktor-Faktor Yang Mempengaruhi Kecurangan (Fraud) Di Sektor Pendidikan Kota Semarang," Account. Anal. J., vol. 3, no. 3, pp. 387-398, 2014.

[2] S. Dellaportas, "Conversations with Inmate Accountants: Motivation, Opportunity and the Fraud Triangle," Account. Forum, vol. 37, no. 1, pp. 29-39, 2013.

[3] K. Rae and N. Subramaniam, "Quality of internal control procedures: Antecedents and moderating effect on organisational justice and employee fraud," Manag. Audit. J., vol. 23, no. 2, pp. 104-124, 2017.

[4] KPMG, "Global Profiles of The Fraudster: Technology enables and weak controls fuel the fraud," Swiss, 2016.

[5] R. Luna-arocas and T. L. Tang, "The Love of Money, Satisfaction , and the Protestant Work Ethic : Money Profiles Among University Professors in the U. S . A . and Spain," J. Bus. Ethics, vol. 50, pp. 329-354, 2004.

[6] L. Tripermata, "Pengaruh Love Of Money, Perilaku Etis Mahasiswa Dan Komitmen Organisasi Terhadap Kecenderungan Kecurangan Akuntansi Dengan Gender Sebagai Variabel Pemoderasi," J. Ilm. Ekon. Glob. Masa Kini, vol. 7, no. 01, pp. 55-62, 2016.

[7] T. L. P. Tang and R. K. Chiu, "Income, Money Ethic, PaySatisfaction, Commitment,and Unethical Behavior:Is Love of Money Root of Evil for Hong Kong Employees?,” J. Bus. Ethics, vol. 46, no. 1, pp. 13-30, 2003.

[8] T. Lau, K. Choe, and L. Tan, "The Moderating Effect of Religiosity in the Relationship between Money Ethics and Tax Evasion,” Asian Soc. Sci., vol. 9, no. 11, pp. 213-220, 2013.

[9] S. W. McDaniel and J. J. Burnett, "Consumer religiusitas and retail store evaluative criteria," $J$. Acad. Mark. Sci., vol. 18, no. 2, pp. 101-112, 1990.

[10] M. Fakhriyadi, "Pengaruh Religiusitas Budaya Etis Organisasi, dan Gaya Hidup Terhadap Fraud di Tempat Kerja," J. Ilm. Mhs. FEB, vol. 5, no. 1, 2017.

[11] T. L. Tang, "Money, the Meaning of Money , Management, Spirituality , and Religion," J. Manag. Spiritual. Relig., vol. 7, no. 2, pp. 173-189, 2014.

[12] L. W. Vona, Fraud Risk Assessment: Building a Fraud Audit Program. New Jersey: John Wiley \& Sons, 2008.

[13] John V Hayes, "Money Attitudes, Economic Locus Of Control, And Financial Strain Among College Students," 2006.

[14] T. L. Tang and H. Liu, "Love of Money and Unethical Behavior Intention: Does an Authentic Supervisor's Personal Integrity and Character (ASPIRE) Make a Difference?," J. Bus. Ethics, vol. 107, no. 3, pp. 295-312, 2014.

[15] T. L. P. Tang, R. Luna-Arocas, T. Sutarso, and D. S. H. Tang, "Does love of money moderate and mediate the income-pay satisfaction relationship?," J. Manag. Psychol., vol. 19, no. 2, pp. 111135, 2004.

[16] M. Aydemİr and Ö. Eğİlmez, "An Important Antecedent of Ethical / Unethical Behavior : Religiosity,” Eurasian J. Bus. Econ., vol. 3, no. 6, pp. 71-84, 2010.

[17] S. E. Krauss, T. Suandi, J. Rumaya, and J. H. Manap, "Exploring regional differences in religiosity among Muslim youth in Malaysia," Rev. Relig. Res., vol. 47, no. 3, pp. 238-252, 2006.

[18] S. E. Krauss and A. Hamzah, "Adaption of a Muslim religiosity scale for use with four different faith communities in Malaysia," Rev. Relig. Res., vol. 49, no. 2, pp. 147-164, 2007.

[19] R. Z. Elias and M. Farag, "The Relationship Between Accounting Students' Love Of Money And Their Ethical Perception,” Manag. Audit. Journal, vol. 25, no. 3, pp. 269-281, 2010. 
[20] T. L. P. Tang and Y. J. Chen, "Intelligence Vs Wisdom: The Love of Money,Machiavellianism, and Unethical Behavior Across College Major and Gender," J. Bus. Ethics, vol. 82, no. 1, pp. 1-26, 2008.

[21] K. T. Yamauchi and D. J. Templer, "The development of a money attitude scale," J. Pers. Assess., vol. 46, no. 5, pp. 522-528, 1982.

[22] E. L. J. Worthington, "Worthington, Everett L., J., Understanding the Values of Religious Clients: A Model and Its Application to Counseling," J. Couns. Psychol., vol. 35, no. 2, pp. 166-174, 1998.

[23] I. Hafizhah, Y. M. Basri, and Et.al, "Pengaruh Etika Uang (Money Ethics) terhadap Kecurangan Pajak (Tax Evasion) dengan Religiusitas, Gender, dan Materialisme sebagai Variabel Moderasi (Studi pada WPOP yang Melakukan Kegiatan Usaha atau Pekerjaan Bebas di Pekanbaru)," J. Online Mhs. Bid. Ilmu Ekon., vol. 3, no. 1, pp. 1652-1665, 2016.

[24] F. K. Şentürk and M. Bayirli, "Relationship between the Islamic Work Ethic and the Love of Money,” Int. J. Res. Bus. Soc. Sci., vol. 5, no. 3, pp. 95-110, 2016.

[25] N. Zahrah, S. Norasyikin, A. Hamid, S. H. A. Rani, and B. A. M. Kamil, "Enhancing Job Performance through Islamic Religiosity and Islamic Work Ethics," Int. Rev. Manag. Mark., vol. 6, no. s7, pp. 195-198, 2016.

[26] A. Singhapakdi, S. J. Vitell, D. J. Lee, A. M. Nisius, and G. B. Yu, "The Influence of Love of Money and Religiusitas on Ethical Decision-Making in Marketing," J. Bus. Ethics, vol. 114, no. 1, pp. 183-191, 2013.

[27] I. A. Indonesia, "Pertimbangan Atas Kecurangan Dalam Audit Laporan Keuangan," 2001.

[28] S. Thoyibatun, "Analysing The Influence of Control Compliance and Compensation System Unthical ehaviour and Accouning fraud Tendency," in Simposium Nasional Akuntansi XII Palembang, 2009, pp. 1-25. 